DOI: https://doi.org/10.32839/2304-5809/2020-12-88-50

УДК 130.2

Шпачинський І.Л., Воронюк К.Р.

Миколаївський національний університет імені В.О. Сухомлинського

\title{
МЕДІАФІЛОСОФІЯ: ДЕЯКІ АСПЕКТИ ФІЛОСОФСЬКОГО ОСМИСЛЕННЯ ПОНЯТТЯ «МЕДІА»
}

\begin{abstract}
Анотація. У даній статті проаналізовано поняття «медіафілософія», уточнено його зміст і підходи науковців до цього поняття. Виділено ряд важливих медіафілософських проблем. Також описано медіафрілософське трактування таких феноменів, як «медіа» і «медіареальність», яке підштовхнуло нас до розгляду медіафілософії як інструменту на шляху до розуміння медіапростору і апробації головних проблем досліджуваної галузі під кутом фахової професійної дисципліни «Технології масмедійної комунікації (Основи теле- та радіожурналістики)» і практики на базі миколаївського інтернет-видання. Розроблено пункти, які допоможуть кожному у повсякденній взаемодії з медіа-ресурсами. Доведено, що дослідження цих проблем - це важлива віха для сучасності і розвитку людства, адже медіа-ресурси стали невід'емною частиною нашого життя.
\end{abstract}

Ключові слова: медіа, медіафілософія, комунікація, філософія, медіареальність, медіапростір.

Shpachynskyi Ihor, Voronyuk Kateryna Mykolaiiv National University named after V.O. Sukhomlinsky

\section{MEDIAPHILOSOPHY: SOME ASPECTS OF PHILOSOPHICAL UNDERSTANDING OF THE CONCEPT OF «MEDIA»}

Summary. This article analyzes the concept of «media philosophy», clarifies its content, approaches of scientists to this concept and also emphasized the importance of the concept A number of important media philosophical problems are highlighted. Media philosophy sees critical changes in the very matter of our daily lives, it is interested in the transformation of current reality and therefore it is important to transform the media environment into the life of modern humankind. Marshall McLuhan emphasized that electronic media is an explosion in communication. They create a special media environment that determines the fate of the modern individual and society. Also the philosophical interpretation of such phenomena as «media» and «media reality» are described in this article, media is understood not just as a means of communication, but as an environment in which interactions take place. These phenomena prompted us to consider media philosophy as a tool on the way to understanding the media space and testing the main problems of the studied field (such as the problem of form, as the destruction of the whole cultural system, the issue of media time and media space, the ordering of information chaos, etc.) from the angle of professional discipline «Technologies of mass media communication (Fundamentals of TV and radio journalism)» and practices on the basis of the Nikolaev online-magazine. In the new world of media reality, everyone should be careful with the huge flow of information, so in this article we have developed items to help everyone in their daily interaction with media resources. Research into these issues has been shown to be an important milestone for modernity and humankind development, as media resources have become an integral part of our lives. In the article, we came to the conclusion that the media participates in the formation of reality for a person, since our perception by its nature is also medial. Media disciplines are gaining prominence and legitimacy both in academia and beyond. This fact pushes us to assert the urgency of the need to study the media in the course of philosophy of education.

Keywords: media, media philosophy, communication, philosophy, media reality, media space.

$\Pi$ остановка проблеми. Якщо в основі лінгвістичного повороту лежить максима: «все є текст», а іконічного повороту - «все $е$ образ», то медіальний поворот, на думку В. В. Савчука, грунтується на основній тезі медіафрілософії - «все $є$ медіа» [5]. Отже, це означає, що практично всі предмети і процеси можна розглядати як медіа, тобто як способи передачі значень або певного сенсу. Об'єднує ці підходи той фракт, що медіафрілософрія $є$ поєднанням двох галузей - фрілософрії і медіа.

Проблема осмислення медіа і медіареальності як складових сучасності є особливо актуальною. I аналіз цих двох понять доречно проводити саме через призму філософрiї, адже вона дає абстрактне і фрундаментальне розуміння досліджуваних фоеноменів.

Аналіз останніх досліджень і публікацій. У зарубіжній фрілософії кінця XX - початку XXI ст. звернення до терміну «медіаповорот» актуалізувалося в контексті інформаційного суспільства, віртуальної реальності, ролі медіа в житті суспільства. Різні позиції були представлені М. Маклюеном, Ж. Бодрійяром, Н. Луманом, Д. Рашкофрдом, М. Кастельсом, Е. Тофрфлером та ін. Але саме біля витоків медіаповороту або медіареволющї стояв М. Маклюен, який в 60-ті роки ХХ ст. першим заявив про універсальну ролі медійних процесів в історичному розвитку, про трансформацію самих медіа, з одного боку, а з іншого, про те, що зміна мас-медіа призводить до трансформащії кожної складової суспільства. Цю думку він викладає в роботі «Галактика Гуттенберга» і підкреслює, що суспільний розвиток обумовлений не зростанням продуктивних сил, які не змінюють фрорми власності, а засобами зв'язку, медіа, на основі яких здійснюеться комунікаця між людьми [3].

Виділення не вирішених раніше частин загальної проблеми. У статті висвітлені і проаналізовані різні погляди на проблематику медіadpiлософріï і їі становлення. Апробовано головні питання і проблеми медіафілософрї̈ в контексті 
фрахової профресійної дисципліни «Технології масмедійної комунікації (Основи теле- та радіожурналістики)» і практики в інтернет-виданні.

Метою даної статті $є$ формування цілісного уявлення і розуміння сутності феномену сучасної медіареальності та її фрілософрського осмислення.

Виклад основного матеріалу. Феномен медіа один з найпопулярніших і найактуальніших в сучасній теорії. Дисципліни медіа отримують розповсюдження і легітимацію як в академічному середовищі, так і за його межами. I це не дивно, адже породжені в медіа образи, моделі, техніки «вростають» у свідомість і тіла. Сьогодні, в епоху цифрових медіа, вони створюють наш світ, а його сприйняття, усвідомлення і переживання здійснюеться за пропонованими медіа правилами. Медіа визначають наше існування, і теорія відповідає цій ситуації пошуками концептуальної мови, адекватного опису нової дійсності - медіареальності. Концептуальна мова медіа - поняття двозначне. Можна говорити про медіа як про об'єкт, так і інструмент аналізу, джерело всіх можливих форм розуміння сучасної дійсності.

Перш за все, варто відзначити, що за останні два десятиліття слово "медіа" як в наукових дискусіях, так i в повсякденному слововживанні звучить все частіше і все наполегливіше. Ми стикаємося 3 ним у лексиконі журналістів, PR-менеджерів, програмістів, військових, політиків, але також знаходимо його і в академічній мові, в гуманітарному напрямі, обговорюваному в різних областях від фрілології до соціології, від теорії комунікації до власне фрілософрії.

Безсумнівно, така широта використання терміну часом заважає його змістовній визначеності. А значить, не зайвим було б нагадати основні смисли, які пов'язані з цим терміном. Слово «медіа» як стійке поняття отримало широке використання в журналістському середовищі і відповідно буквальному значенню, асоціювалося із засобами масової інформащії.

Трохи пізніше з журналістського середовища термін «медіа» потрапив в сферу уваги соціології. Почався період критичного осмислення як самого поняття, так і означеного ним феномена.

Відомо, що медіа перестали розглядати тільки в значенні посередників між вихідною подією і реципієнтом цієї події, в них визнали інструмент маніпулювання громадською думкою медіа не стільки транслюють інформацію, скільки визначають форми сприйняття ціеї інформації [7]. Тут бере початок аналітика феномена медіа, яка, тим не менш, обмежується дослідженнями історичних, соціальних і політичних едектів медіа в суспільному житті людства.

На думку фрілософра М. Маклюена, не соціальні, а комунікаційні револющії, революції в медіа, призводять до зміни в розвитку суспільства. Основу цих процесів вчений бачить у появі електронних мас-медіа. Електронні мас-медіа - це вибух у комунікації. Вони створюють особливе медіасередовище, яке визначае долю сучасної людини і суспільства: «Зміни, що вносяться використанням електрики, пов'язані з автоматизацією, не мають нічого спільного ні з однією програмою суспільного устрою» [4, с. 10].

В інтерпретації М. Маклюена мас-медіа виступають посередником, сполучним фрактором суспільного життя і включають в себе усне слово, рукописне слово, друк, радіо, телебачення, сприяють генерації інформації, смислів і цінностей в процесі взаємовідносин соціальних суб'єктів. Мас-медіа, у роботах вченого, мають значення сучасних засобів масової індормації і комунікаціï. Філософр розглядав мас-медіа в контексті медіасередовища в рамках певних соціокультурних відносин, визначальним фрактором яких є спосіб комунікації, точніше - технологія, а соціальна еволюція виступає як зміна, вдосконалення, розвиток, трансформація різних типів мас-медіа.

М. Маклюен прогнозував вирішальну роль електронних аудіовізуальних мас-медіа для соціокультурного прогресу. Згідно з цим прогнозом, панівне місце буде належати не письмово-друкованим, а усно-електронним формам спілкування, які скорочують простір, час і відносини, повертаючи нас до множинності відносин одночасно, тим самим, залучаючи до нових «ритуальностей» i «мов» глобальних радіо- і телевізійних зв'язків.

Спадщина М. Маклюена зберігається, адже дослідники медіа ще досі прагнуть віднести себе до одного 3 таборів, позначених в його творчості: або до дослідників медіа як матеріальних предметів - технічним артефрактів, або до аналітиків медіа, який розглядає теорії та закони.

Натхненниками перших виступають фрранцузькі мислителі Жильбер Сімондон і Андре Леруа-Гуран. Для Леруа-Гурана, техногенез - розвиток техніки в широкому сенсі: еволюція технічних об'єктів, технік ритуалу, технік письма, естетичних технік, які в своїй єдності створюють технічне середовище як життевий світ людини, тобто обумовлюють антропогенез (процес розвитку).

Ж. Сімондон пішов ще далі, в ході продумування генетичних законів, керуючих технічною еволюцією, він показує, що зовсім не людина як мисляча істота має бути звільнений від техніки, так як думка неможлива поза техніки, але техніка як актуальна форма розуму повинна бути звільнена від розумового мислення людини, скутого нормами економії і розрахунків.

Побічно продовжуючи цю традицію, Ламберт Візінг - один з найбільш авторитетних сучасних дослідників, що працюють в руслі феноменології медіа, говорить про те, що медіа - це явище, що дозволяе переходити фрізичному в нефрізичне (смислове) і назад [10]. Людина ще не вникла в суть процесів, які дозволяють їй орієнтуватися в світі, не пізнала їх справжню долю, виявилась в тіні несвідомого, вона використовує, але не розуміе їх, і в цьому трагедія технічної цивілізації.

Другий «табір» розглядае метатеорії медіа та їх епістемологічні закони. Натхненником тут $є$ Ніклас Луман. Введена ним соціологічна концепція медіа як виробництва зв'язків між речами, подіями, значеннями у творчості наступних мислителів перетворюеться в фрілософрський ключ і з часом в нову онтологію [2].

Ототожнювальні спочатку 3 інформаційнокомунікаційними технологіями, медіа в пізніших фрілософрських дослідженнях аналізуються як справжня продуктивна сила. Приходить усвідомлення тієї обставини, що медіа не просто роблять технічно можливою передачу інформації або інтерсуб'єктивності комунікації, а й кардинально змінюють як сутність комунікації, так 
і сутність інформащії: повідомлення вони перетворюють в «повідомлення» - введення в нову спільність, в світ нових смислових зв'язків, а індрормацію - в «інформацію» як вступ до нової буттевої форми.

Німецький фрілософр Райн хард Марграйтер навіть вважає, що пов'язаний з іменами Мартіна Хайдеггера та Миколи Гартмана, «онтологічний поворот» можна повторити сьогодні тільки як «поворот до медіа» [8].

Тобто, дивлячись на нові тенденщії, не дивно, що у фрілософії виник новий напрям. Медіафілософрія є перспективною галуззю фрілософрї, що бере свій початок 3 XX століття. Вона містить цілий список особливо актуальних питань комунікативного поля сучасного суспільства, а також набуває онтологічного та епістемологічного статусу. Зокрема, як зазначав дослідник медіафілосодрiї М.Г. Санакуев, вести мову про онтологію нам дає підстави поняття медіареальності, що являє собою віртуальний простір, а епістомологічного характеру медіафрілософрія набуває завдяки медійності як здатності до пізнання. Одними 3 найголовніших проблем цього напряму фрілоcodpiï $є$ питання образу як рушійної сили всієї культурної системи, а також проблема медіачасу та медіапростору, вони є тісно пов'язаними та наслідують класичну традицію ототожнення часу з простором, проте суттєвою відмінністю $є$ порушення лінійного часового континууму, що створює ряд труднощі [6]. Усе це потребує від науковців вироблення нового критичного осмислення, а також впорядкування інформаційного хаосу, що 3 часом, тільки наростає.

Медіафрілософрія працюе з поняттями, що виникають в контексті сучасного медіасвіту. Цю точку зору ілюструе висловлювання Штедрана Мюнкера: «Саме в той самий момент, коли весь наш життєвий світ характеризується зверненням до так званого нового: з електронними та цифровими медіа, така наукова дисципліна, як медіафрілософрія є виправданою і необхідною» [9, с. 18].

Медіафрілософрія відстежуе критичні зміни в самій матерії повсякденності, цікавиться трансдормацією актуальної реальності і тому їй важливо перетворення медіасередовища в життєвий світ сучасної людини. Тут порушуеться цілий ряд не менш важливих медіафрілософрських проблем: розсіювання культурної ідентичності в соціальних мережах та збирання медіасуб'єкта, візуальна екологія, освітня функція медіа, конструювання гендеру засобами медіа, мережеве споживання i iнформаційний голод, програмування в медіа нудьги, болю, екстазу, диктатура мас-медіа-розваг.

Медіафілософія не втомлюеться нагадувати нам про характерну рису часу - про те, що світ перестає бути легко доступним для огляду, свідомість прозорою, існування автономним. Наша свідомість дискримінована невизначеністю, а розуміння медіа і зовсім, завжди не визначено, в цій ситуащії необхідно гранично уважно ставитися до контексту думки, до умов їі реалізації. Кожен формат культури має на увазі свій формат медіа, і в цьому сенсі розуміння медіа означає також і перемикання формату, вміння бачити, як інший, розуміти мову іншого, його коріння та підстави.

Для того, щоб систематизувати фрілософрські напрямки досліджень медіа, можна, слідом за
Ламбертом Візінгом, [1] виділити шість основних підходів:

1) медіафілософрія як фрілософрська розробка поняття медіа;

2) медіафілософрія як фрілософрія, яка здійснюеться через медіа;

3) медіафілософрія як рефлексія понятійних проблем, пов'язаних з появою нових (електронних) медіа;

4) медіафілософія як аналіз «медіального повороту»;

5) медіафілософія як основний дискурс культурології та медіадісціплін;

6) медіафрілософіï не існуе.

Сучасні дискусії про основні проблеми медіафрілософрії неможливі без ретельної розробки всіх вищевказаних проблем, без їх зваженого i peтельного аналізу.

Я мала шанс зіткнутися з деякими проблемами описаної галузі фрілософії під час практики в миколаївському інтернет-виданні i безпосередньо при підготовці до ціеї практики під час вивчення фрахової профресійної дисципліни «Технології масмедійної комунікації (Основи телета радіожурналістики)». Адже головним поняттям у журналістиці $є$ інформація, 3 якою якраз і пов'язані головні проблеми медіафрілософрї: проблема образу, як рушійної сили всієї культурної системи, питання медіачасу та медіапростору, упорядкування інформаційного хаосу і т.д.

При наданні інформації людині можна перебільшити значущість одного фрактора, зменшити або зовсім забути про якийсь інший чинник. Так само сам людський мозок несвідомо може блокувати небажану інформацію. Ще одна особливість мислення, яка заважає роботі здоровій логіці це асоціативність і загальна тенденція швидше забувати хороше (а іноді зовсім не помічати), ніж погане. Цим в основному і користуються всі медіа-ресурси. Коли ми бачимо в новинах, що все стабільно погано, варто задатись питанням «А чи все справді так?». Також у медіа часто використовують інструмент створення певного медіаобразу, який користуватиметься популярністю і викликатиме довіру у людей або навпаки, викликатиме негативні емощї.

Тому, для того, щоб уникнути такого, варто пам'ятати, що тому, хто надає інформацію, вигідно показувати погане, адже таке привертає набагато більше уваги і захоплюе емоції, також варто навчитись фрільтрувати ваші джерела інформації, піддавати все сумніву і переглядати декілька ресурсів.

Висновки і пропозиції. Отже, на власному досвіді, я впевнилась в тому, що точка зору Ламберта Візінга імпонуе мені найбільше, адже з опорою на мою фахову практику в інтернет-виданні, можу сказати, що науковець правий в тому, що медіа - це те явище, яке людина ще достеменно не дослідила і не "підкорила», адже люди кожного дня зіштовхуються 3 величезним потоком індрормації, яким ще не вміють користуватись і не вміють його фрільтрувати, відповідно, багато медіаресурсів користуються цим в своїх інтересах.

Тобто, роль медіа в сучасному житті настільки велика, що нинішне суспільство характеризують не тільки як «інформаційне», не тільки як «суспільство знань», «постіндустріальне суспіль- 
ство», але і як «медіальне», тобто суспільство, що «обумовлене медіа». Медіа стало новим явищем, яке активно просувається в усі сфери життя як суспільства, так і особистості, трансформуючи світогляд, цінності, установки, моделі поведінки, політичні оріентири. Мабуть, сьогодні немає такого сегмента життя суспільства і людини, які не відчули б на собі вплив медіа.

Взаемодія медіа та dpiлософрії не відноситься до так званих «вічних» фрілософрських проблем. Ця взаємодія - складова більш широкого фрілософрського дискурсу - фрілософрського осмислення медіа, одним з проявів якого і є медіафілософрія. Медійність - новий атрибут фрілософії, її нова характеристика, особливість, яка потребуе більш грунтовного дослідження.

Медіафрілософрія мислиться не як фрілософрія певних медіа, а як специфічний, що відповідає духу часу, тип самої фрілософіï, сучасний спосіб ӥі побутування.

Також відзначимо, що медіафілософія досить продуктивна в якості підходу до дослідження такого феномена, як медіапростір. Медіа розуміеться не просто як засіб комунікації, але як середовище, в якому відбуваються взаємодії. Медіафрілософрія як напрям можна умовно позначити терміном «медіадетермінізм», оскільки відповідно до нього процес сприйняття, пізнання і діяльності людини в принципі досліджується в залежності від медіа. В цьому і вбачаємо подальші Iрунтовні дослідження в галузі медіафілософії, i для пророблення більш детального концептуального підгрунтя, особливо з упором на відповідні позитивні практичні наслідки, пропонуємо ввести це поняття в поле осмислення такого напрямку, як фрілософрія освіти.

\section{Список літератури:}

1. Визинг Л. Шесть ответов на вопрос: «Что такое медиафилософия?». Вестник ЛГУ ил. А.С. Пушкина. Серия "Философбяя". 2010. № 3. Т. 2. С. 189-193.

2. Луман Н. Реальность массмедиа. Москва : Праксис, 2005. 253 с.

3. Маклюэн М. Галактика Гутенберга: сотворение человека печатной культуры : пер. с англ. А. Юдина. Москва : Ника-Центр, 2003. 432 с.

4. Маклюэн М. Понимание медиа. Внешнее расширение человека : пер. с англ. В. Николаева. Москва, Жуковский : КАНОНПресс-Ц, Кучково поле, 2003. 464 с.

5. Савчук В.В. О предмете медиафилософии. Культурная история медиа. Международный журнал исследований культуры. 2011. № 3(4). C. 6-10. URL: https://cyberleninka.ru/article/n/o-predmete-mediafilosofii/viewer (дата звернення: 16.12.2020).

6. Санкуев М.Г. Медіафілософрія як нова галузь фрілософрського знання. Гілея. 2014. Вип. 89. С. $199-202$. URL: https://www.researchgate.net/publication/322699168_Mediafilosofia_ak_nova_galuz_filosofskogo_znanna (дата звернення: 16.12.2020).

7. Lasswell H.D. Propaganda Technique in World War I. Cambridge, Mass. : MIT Press, 1971. 233 p.

8. Margreiter R. Realitaet und Medialitaet. Zur Philosophie des Medial Turn. Medien Journal. Zeitschrift fuer Kommunikationskultur. 1999. № 1(23). S. 9-18.

9. Münker S. After The Medial Turn. Sieben Thesen zur Medienphilosophie. Medienphilosophie. Beitrage zur Klarung eines Begriffs / S. Münker, A. Roesler, M. Sandbothe, 2003. P. 18-20.

10. Wiesing L. What are Media? Techné/Technology. Researching Cinema and Media Technologies - Their Development, Use and Impact / ed. A. van den Oever. Amsterdam : Amsterdam University Press, 2014. P. 93-104.

\section{References:}

1. Vizing L. (2010) Six answers to the question: «What is media philosophy?». Bulletin of LSU named after A.S. Pushkin. "Philosophy» series, no. 3, t. 2, pp. 189-193.

2. Luhmann N. (2005) The reality of the mass media. Moscow: Praxis, $253 \mathrm{p}$.

3. McLuhan M. (2003) Gutenberg's Galaxy: the Creation of Man of Print Culture: trans. from English by A. Yudina. Moscow: Nika-Center, $432 \mathrm{p}$.

4. McLuhan M. (2003) Understanding the media. External expansion of the person: lane. with English V. Nykolaeva. Moscow, Zhukovsky: KANONPress-Ts, Kuchkovo Pole, 464 p.

5. Savchuk V.V. (2011) On the subject of media philosophy. Cultural history of the media. International Journal of Cultural Studies, no. 3(4), pp. 6-10. URL: https://cyberleninka.ru/article/n/o-predmete-mediafilosofii/viewer (accessed 16.12.2020).

6. Sankuev M.G. (2014) Media philosophy as a new branch of philosophical knowledge. Gilea, iss. 89, pp. 199-202. URL: https://www.researchgate.net/publication/322699168_Mediafilosofia_ak_nova_galuz_filosofskogo_znanna (accessed 16.12.2020).

7. Lasswell H.D. (1971) Propaganda Technique in World War I. Cambridge, Mass.: MIT Press, 233 p.

8. Margreiter R. (1999) Realitaet und Medialitaet. Zur Philosophie des Medial Turn. Medien Journal. Zeitschrift fuer Kommunikationskultur, no. 1(23), pp. 9-18.

9. Münker S. (2003) After The Medial Turn. Sieben Thesen zur Medienphilosophie. Medienphilosophie. Beitrage zur Klarung eines Begriffs / S. Münker, A. Roesler, M. Sandbothe. Pp. 18-20.

10. Wiesing L. (2014) What are Media? Techné/Technology. Researching Cinema and Media Technologies - Their Development, Use and Impact / ed. A. van den Oever. Amsterdam: Amsterdam University Press, pp. 93-104. 